\title{
Financial Development, Urbanization, and Urban-Rural Income Disparity: Evidence Based on Chinese Provincial Data
}

\author{
Zhiqiang Ye*, Lixia Qian*, Zhang Na \\ Department of Finance, School of Business, East China University of Science and Technology, Shanghai, China \\ Email: *lxw0521@163.com, * qianmoyouzi@sina.com
}

How to cite this paper: Ye, Z.Q., Qian, L.X. and Na, Z. (2018) Financial Development, Urbanization, and Urban-Rural Income Disparity: Evidence Based on Chinese Provincial Data. Modern Economy, 9, 31-60. https://doi.org/10.4236/me.2018.91003

Received: November 9, 2017

Accepted: January 5, 2017

Published: January 8, 2017

Copyright $\odot 2018$ by authors and Scientific Research Publishing Inc. This work is licensed under the Creative Commons Attribution International License (CC BY 4.0).

http://creativecommons.org/licenses/by/4.0/

\begin{abstract}
China's economic development has maintained a rapid growth trend since 1978, but the problem of imbalanced income distribution between urban and rural residents also has been increasingly aggravated. This paper discusses the relationship between financial development and urban-rural income disparity and examines the impact of urbanization on the relationship between financial development and urban-rural income disparity. Then this paper selects the provincial panel data of 28 provinces in China from 1978 to 2014, using GMM dynamic model and fixed effect panel model, respectively, to do the empirical test. The results show that: 1) the imbalance of urban and rural financial resources is exacerbated by the financial threshold effect, leading to the fact that the financial development-measured by scale, efficiency and structure, respectively, expand the urban-rural income gap. 2) The developing urbanization will widen the urban-rural income gap. However, as the urbanization and mainly the urbanization of land is rapid in China, the expansion effect of the increasing financial development level on the income gap between urban and rural residents in China will be weakened with the acceleration of urbanization based on the financial threshold effect. It provides empirical support for the financial reform and for the assumption that urbanization development reduces the income gap between urban and rural areas.
\end{abstract}

\section{Keywords}

Financial Development, Urban-Rural Income Gap, Urbanization, Financial Threshold Effect

\section{Introduction}

Since 1978, China's economic development has maintained a high-speed growth 
trend. The achievements in economic construction have been witnessed, such as the improvement of resident income, the vigorous evolution of the financial market, and the smooth progress of urbanization. World Bank data showed that in 2015 China's GDP reached 10.87 trillion yuan, annual GDP growth rate is 6.9\%, far higher than the world average, per capita GDP reached 7924.65 US dollars. However, China still faces serious obstacles and challenges on its way to be the global economic leader: on one hand, China's per capita income level, financial development and urbanization quantity and quality indicators are still low; on the other hand, the national wealth accumulated by economic growth has not been evenly distributed among all residents, in particular between the income of urban residents and that of rural residents. According to the National Bureau of Statistics, the absolute difference in disposable income between urban and rural residents in 1978 was 209.8 yuan and the relative difference was 2.57: 1 ; in 2014, this figure increased to 19,489 yuan and 2.91:1-the absolute difference expanded nearly 92 times. The imbalance of income distribution between urban and rural residents has become a major problem to be solved urgently for China's economic development. How to reverse the trend of widening the income gap between urban and rural areas is of urgent practical significance. With the advancement of the reform process, the rate of urbanization in China has also been improved, from $19.92 \%$ in 1978 to $55.6 \%$ in 2014 , increased by $36 \%$, much faster than that in other developing countries. The acceleration of urbanization in China has an important impact on the allocation of financial resources and the income level of urban and rural residents.

This paper does an empirical test on the relationships between financial development, urbanization, and urban-rural income gap. The research clarifies the influence path and mechanism of each other, and had important theoretical and practical significance. Theoretically, scholars in the past mainly focused on the topic of financial development and economic growth. Until the 1990s, economists began to formally focus on financial development in improving the role of income distribution, but they have not yet reached a consensus on the debate that financial development whether or not improve the pattern of income. Liu and $\mathrm{Yu}$ [1] conclude that China banking structure dominated by the four state-owned commercial banks is not conducive to the development of SMEs and thus not conducive to reducing the present economic disparity. Jalil and Feridun [2] uses ARDL model to invistigate the relationship between Gini coefficient and financial development and finds financial development leads to a reduction in the income inequality. Hence, whether the financial development narrows the gap in income distribution in China needs to be explored further. In this paper, we will use the panel data from 1978 to 2014 in China to explore the impact of financial development on the income gap between urban and rural residents under the threshold mechanism, and to analyze the internal relations and mechanisms. This paper provides the evidence to support the conclusion that "financial development will hinder the narrowing of income gap" based on 
the provincial data of our country. In addition, urbanization is a significant driving force of modern economic and social development. Financial development, urbanization, and urban-rural income gap are closely related. Lu and Chen [3] analyzes of the provincial panel data during 1987-2001 shows that urbanization significantly narrowed the urban-rural inequality. Su et al. [4] applies bootstrap panel Granger causality to test the relationship between urbanization and the urban-rural income gap in China. We find that patterns of interaction between urbanization and the urban-rural income gap vary according to different regions. Empirical results show that urbanization does Granger-cause an urban-rural income gap, mainly in the Eastern region of China. In one-third of all provinces, the urbanization levels have a significant impact on the urban-rural income gap; however, the urban-rural income gap does not play a significant role in urbanization. This paper firstly studies the relationship between financial development and urban-rural income disparity in the light of urbanization and introduces the interaction between urbanization and financial development in the empirical research. This paper examined the impact of financial development on the urban-rural income gap influenced by the urbanization. This paper expands the scope of financial development and urbanization research in the light of the difficulties encountered in the process of urbanization in China. This study provides a vision for the future development and implementation of reasonable financial policies which can promote the coordinated development of urban and rural economy, reduce or narrowing the income gap between urban and rural residents, and achieve stable and healthy economic and social development. Plus, analyzing the impact of urbanization on the relationship between financial development and urban-rural income gap can uncover the problems in the process of rapid urbanization in China, and provide evidence for policy-making and enhance the quality of urbanization as well.

\section{Institutional Background and Theoretical Analysis}

Financial development is a complex concept. Thus a simple indicator of financial development is difficult to reflect all the information. Based on the data availability and the general practice, this study used the scale, structure, and efficiency of bank credit to quantify financial development. The "60 Years of New China Statistical Data" and "China Statistical Yearbook" provided data of bank credit from 1978 to 2014. Financial intermediaries in China has developed steadily since 1978 and the proportion of bank credit in GDP rose sharply from 0.52 in 1978 to 1.72 in 2014. Compared with other countries, China's financial intermediaries have their unique structural characteristics.

First of all, in China, financial resources are highly concentrated in the city but rural financial suppression is serious. As a result of long-term urbanoriented economic development policies, China's rural population accounts for the vast majority of China's total population, but agricultural loans never accounted for more than $15 \%$ of total loans and it even declined to $3.6 \%$ in 2014 . 
Especially, the agricultural loan business has basically no direct relationship with the farmers, but mainly with the state-owned agricultural management institutions and township enterprises to carry out business. This part of the loan is mainly concentrated in large-scale infrastructure, government bond financing supports and ecological construction loans and other large projects. Because of the cost-based considerations in recent years, the state-owned commercial banks, whose core objective is to gain profits, have strategically retreated from the rural areas while the current financial situation in rural areas is almost completely "anemic".

Second, the big four state-owned commercial banks lead the banking financial intermediate institution. By the end of 2014, the assets of the big four stateowned commercial banks accounted for $55.15 \%$ of the total assets of the banking financial institutions. The deposits accounted for $54.59 \%$ of the total deposits of the banking institutions in China over the same period. The proportion of loans issued of big four state-owned commercial banks out of total loans issued by domestic financial institutions in the same period was $51.25 \%$. A high degree of monopoly of financial institutions will reduce the efficiency of the financial system. According to Levine, Levkov and Rubinstein [5], if banks have strong monopoly power, they will be reluctant to do cost-sensitive project screening. Therefore, even though emerging companies have projects that are more profitable, banks would prefer to lend money to customers with whom they have nepotism, such as state-owned enterprises since it ensured the sufficient and less risky profits. However, it will reduce the efficiency of the financial system and weaken the economic development.

Third, China's financial system is highly nationalized. According to La Porta, Lopez-de-Silanes and Shleifer [6], the Chinese government owned $99.45 \%$ share of the top ten commercial banks in 1995, highest among the sample of 92 countries. A high degree of nationalization of the financial system may also result in the inefficiency of the financial system and the economy. There are two very different views on the relationship between the nationalization of the financial system and the efficiency of the financial system [6]. Gerschenkron [7], a representative of the "development" perspective, argued that in some countries, especially in such as Russia, the private banking system has a hard time playing an important role in the process of economic development. Therefore, in underdevelopment countries, government intervention in the financial system would promote the development of financial intermediaries and economic development. Myrdal [8] also believed that the nationalization of the financial system was conducive to national control of finance and promoted economic development. Shleifer and Vishny [9], the representative of the political view, however, argued that government involvement in the financial system would induce financial intermediation to serve the government's political goals, which can lead to economic inefficiencies. For example, the government provides job opportunities, subsidies, and other benefits to supporters by controlling corporations and 
banks, while supporters reward the government in the form of votes, political cash, and bribes [10]. LLS [6] examined the relationship between the degree of nationalization and economic efficiency of the financial system through crosscountry data and found that the more nationalized financial system meant lower per capita income, less efficient financial intermediation, and lower efficiency of the government and worse protection system of property rights. The high degree of nationalization of the financial system explained to a certain extent that the efficiency of China's financial system is extremely low.

Finally, China has unified national banking and financial system. The big four state-owned banks are headquartered in the capital city of Beijing and jointstock banks and other types of commercial banks located in major developed cities or provincial capitals, leading to the fact that the originally limited rural financial resources flow back to the city to support urban development.

Scholars began to study the issue of income distribution from the perspective of financial development since the 1990s. Greenwood \& Javanovic [11] first formally explored the evolutionary path between financial development, economic growth, and income distribution, providing a normative theoretical basis for the future study of this issue. In Greenwood \& Javanovic's theory of the effect of financial development on income distribution, they argued that financial development and income distribution are not simply expressed as a simple linear relationship, but created a dynamic model (GJ model) which includes economic growth, financial development, and income distribution, based on Kuznets' "inverted U" hypothesis. The analysis of the model demonstrated that the relationship between financial development and income disparity follows the Kuznets' inverted U Type curve. Greenwood \& Javanovic made the following analysis: in the early stage of economic development, the financial market is immature, investors need to pay fixed costs to financial intermediaries in order to benefit from the financial market financing and other activities. Because of the fixed financial participation threshold, the poor cannot cross the threshold and will be excluded from the financial system. Some wealthy people can and will pay a certain cost to cross the financial threshold and invest in financial resources and services. High-risk, high-yielding projects, resulting in substantial revenue growth. The differences in the final return on investment between the two groups, caused by the different levels of initial wealth, have led to a further widening of the income distribution gap. In the mature stage of economic development, financial market development is becoming increasingly perfect. On the one hand, financial intermediaries will take action to lower the threshold level to maintain competition and seize greater market interest; the other hand, the wealth of the poor earned in previous stage also reached the threshold level at which the poor can have access to the same wealthy and the same financial services, and obtain a higher level of investment income rate. As a result, the income gap will tend to narrow until the income distribution pattern eventually stabilized at the equilibrium point. Obviously, the classical GJ model extends the Kuznets' "inverted 
U" hypothesis through the path of financial development: with the continuous development of the economy and the improvement of the financial market, the income gap will demonstrate a " $U$ " track, as the gap widen at first and then narrow.

By the GJ classical model, Townsend \& Ueda [12] simplified and improved the model, and constructed a complete dynamic model. They used non-stationary and non-linear dynamic programming method to empirically explore the impact of financial development on income distribution mechanism. Finally, they found the Kuznets "inverted U" effect between financial development and income distribution mechanism which is consistent with the conclusions of the GJ model, laying a foundation for the subsequent empirical analysis of the corresponding topics.

The empirical analysis has generally been agreed that financial development is conducive to reducing income inequality. From 1977 to 1990, the commercial bank licensing rule of Indian government prompted a large number of commercial bank branches in rural areas. Burgess and Pande [13] found that the Indian government's intervention policy led to a sharp shrink in the urban-rural income gap and a reduction in the poverty level in rural India, even though the rate of economic development is not high during the same period. Clarke, $\mathrm{Xu}$, and Zou [14] studied the relationship between financial development and income inequality through cross-country data and found that financial development favored a decline in the Gini coefficient. Beck, Demirgüç-Kunt, and Levine [15] highlighted the implications of financial development for low-income earners. They found that financial development not only reduced the Gini coefficient but also reduced the ratio of the population living below the average daily cost of $\$ 1$, by using cross-country data and dynamic panel regression methods. Beginning in the mid-1970s, the United States began to loosen regulation of commercial banks on state-level to facilitate the development of financial intermediation. Beck, Levine and Levkov [16] examined the impact of financial development on income inequality under this condition. They found that the state's Gini coefficient decreased significantly when a state relaxed its regional restrictions on commercial banks. At the same time, the income of wealthy families has not diminished.

Therefore, we propose:

H1: the financial development will expand the income gap between urban and rural.

The rapid development of urbanization in China started from 1978 after the implementation of the reform and opening policy. It has made some achievements after nearly 37 years of development. Based on the domestic development process, the results of Figure 1 show that: China's urbanization rate had broken $30 \%$ as early as by 1996; China's urban population reached 523.76 million and the urbanization rate for the first time increased to $40.53 \%$ by 2003 ; the urbanization rate in China has increased from $19.92 \%$ in 1978 to $55.6 \%$ in 2014. 


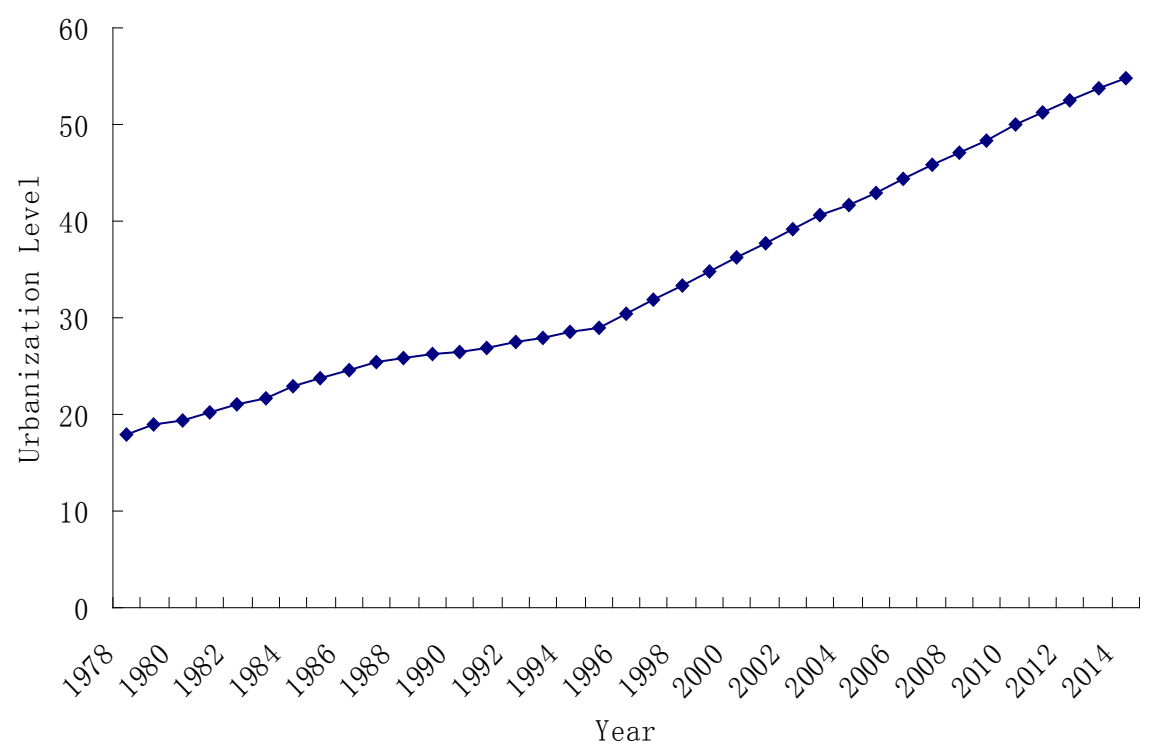

Figure 1. The Development of Urbanization in China (1978-2014). Source: Statistical Yearbook of China for 60 years (1949-2009), China Statistical Yearbook (1983-2015).

Overall, according to Urbanization Stage Theory of Ray. M. Northam, the urbanization process in China is at the stage of acceleration.

Table 1 shows the urbanization of the major countries and regions in the world in 2014: compared with the world average level, the urbanization level of China was under the world average for a long time and reached the average level until 2013. China's urbanization level has reached 55.6\% in 2014, slightly higher than the world average of 53.9\%. Compared with the world's major developed countries, including the United States, Britain and Canada whose urbanization rate are more than $80 \%$, the rates of few of them were even more $(74.7 \%$ of Japan); among major developing countries, there are still some countries having a high level of urbanization, such as Malaysia (74.7\%), Mongolia (72.4\%), and Brazil (85.7\%).

In general, although the process of urbanization in China is at an accelerated stage, the rural population is rapidly converging to urban areas, and the urbanization development in China has achieved relative achievements, the urbanization process lag far behind the developed countries and, even compared with the similar developing countries, China still has relatively low urbanization level.

China's urbanization is far behind the level of economic development, which is related to the long-term "dual urban-rural" economic policy of the Chinese government and mainly caused by the urban-rural split management system. During the period of the planned economy system, China has formed the dual structure of urban and rural economy, which is in line with the implementation of China's catching-up economy development strategy. Under the catch-up strategy, economic resources were concentrated in the urban heavy industry, while the prices of agricultural products were artificially depressed. In addition, the industrial sector restricted the demand for labor by using capital-oriented 
Table 1. Urbanization level in world's major countries (2014).

\begin{tabular}{cccccccc}
\hline $\begin{array}{c}\text { Development } \\
\text { Countries }\end{array}$ & World & US & Canada & Japanese & France & Britain & Australia \\
\hline $\begin{array}{c}\text { Percentage of urban } \\
\text { residents (\%) }\end{array}$ & 53.9 & 81.6 & 81.8 & 93.5 & 79.5 & 82.6 & 89.4 \\
$\begin{array}{c}\text { Underdevelopment } \\
\text { Countries }\end{array}$ & China & Brazil & Malaysia & Mongolia & Philippines Thailand & India \\
$\begin{array}{c}\text { Percentage of urban } \\
\text { residents (\%) }\end{array}$ & 55.6 & 85.7 & 74.7 & 72.4 & 44.3 & 50.3 & 32.7 \\
\hline
\end{tabular}

Source: China Statistical Yearbook (2015), and Data base from Word Bank.

technology. Thus, the household registration system restricted the urban-rural migration for the development of heavy industry. Since the 1978 Reform and Opening, the traditional system of urban-rural dual partitioning situation still maintained. Some large and medium-sized cities restricted farmers entering the good industry and professions by using administrative means directly, because they needed to ensure the employment of urban residents. Meanwhile, some economic measures have also been used to increase the cost of rural labor migration. Enterprises employing rural labor force are required to pay a certain administrative fee, and migrant workers were treated discriminately in term of social security, compulsory education, public service and rights protection. This urban-rural dualism system greatly limited the labor moving between urban and rural in China. The rural migrant workers cannot have the same rights as the urban residents due to the current household registration system, greatly increasing the uncertainty of the income of migrant workers. While urban housing costs are very high and prevents the family migration of migrant workers.

Urbanization and financial development are closely related. The urbanization needs the corresponding infrastructure construction and public services. In the process of rapid urbanization, due to the limited tax revenue of local governments, it is difficult to meet the financial needs of large-scale rapid urbanization, and it is necessary to resort to financial markets to ease the financing constraints in the process of urbanization. Stopher [17] and Chang et al. [18] analyzed the financing constraints faced by US railroads in the process of urbanization and water resources development in China's urbanization. They found that financial development was the bottleneck in alleviating urbanization financing and played an important role. Kim [19], Cho \& Boggess [20] claimed that the financial development that provided the financial support for the process of land investment and real estate construction accelerated urbanization process. In addition, in China's typical urban-rural dual economic structure, the city brings together a large number of capital and technology-intensive enterprises while rural areas are mainly labor-intensive enterprises. Hence, urban development needs more financial resources. Financial development will reduce the cost of financing and raise the efficiency of financing by eliminating the information asymmetry, moral hazard and adverse selection in the financing market, effectively alleviat- 
ing the problem of financing constraints. The solution to financing constraints facilitates capital and technology-intensive enterprises far greater than for labor-intensive enterprises. Urbanization turns rich rural residents into urban residents and changes the demographic structure of urban residents and rural residents, which has a direct impact on urban-rural income disparity. Moreover, the urbanization process along with the flow of financial resources will expand the urban-rural income gap. China is a unified financial market, especially the big four state-owned banks are national financial resources which can achieve the country-wide mobility of financial resources as well as the freedom of movement between rural and urban areas. Therefore, the urbanization needs to invest more financial resources in cities and towns, to support the improvement of urban infrastructure, increase the development opportunities of urban residents, and to improve the income of urban residents. On the contrary, the lack of financial resources in rural will slow the increase in rural income, causing the financial resources flow from rural to the city. Also, the urbanization in China is under the government guidance. Local governments pursue GDP growth to create personal achievement and the agricultural growth rate is lower than the growth rate of non-agricultural industries. Thus the government often gives priority to the development of urban non-agricultural industries by various means to move the financial resources into the industries which support urbanization.

However, a prominent phenomenon of urbanization in China is "urbanization of land" rather than "population urbanization". Although the urbanization in China reached $55.6 \%$ in 2014, the spatial urbanization did not facilitate corresponding population urbanization. Consequently, it became a forced urbanization or Pseudo-Urbanization in China. The local government has limited tax revenue since the implementation of fiscal and taxation reform in 1994,. Their revenue mainly relied on land finance, expansion of urban areas, and the transformation of the suburban landless farmers into urban residents, but did not lift the level of economic development, increase the employment, and adjust industry structure. In the second session of the 2012 Urban Management Forum in the National Development and Reform Commission, Ruiling Qiao, deputy director of the small and medium-sized town, said the level of China's urbanization will re-calculate to at least the one-third less without exaggeration. Besides, this transformation of the low-level new urban residents will have more financial resources. Banks and other financial institutions require fixed income and proof of property to provide financing service. The new urban residents from outskirts lack a stable source of income and sufficient fixed assets. Because of the threshold of financial development, the new urban residents are often excluded by finance institution, such as banks.

Therefore, we propose:

$\mathrm{H} 2$ : urbanization will decrease the influence of the financial development on the income gap between urban and rural. 


\section{An Empirical Analysis of Financial Development and Urban-Rural Income Gap}

\subsection{Model Design}

This paper examined whether the financial "threshold effect" leads to the imbalance in the allocation of financial resources between urban and rural areas, and then causes the widen income gap between urban residents and rural residents. According to Clarke, Xu and Zou [14] and Beck, Demirgüç-Kunt and Levine [15] and other literatures on the relationship between financial development and urban-rural income disparity, we revised the model by re-screening indicators, and then set up the following four measurement models:

$$
\begin{gathered}
\operatorname{Gap}_{i, t}=\beta_{1} \operatorname{Gap}_{i, t-1}+\beta_{2} \mathrm{Fin}_{i, t}+\beta_{3} X_{i, t}+\alpha_{i}+\eta_{t}+\varepsilon_{i, t} \\
\operatorname{Gap}_{i, t}=\beta_{1} \operatorname{Gap}_{i, t-1}+\beta_{2} \mathrm{Fe}_{i, t}+\beta_{3} X_{i, t}+\alpha_{i}+\eta_{t}+\varepsilon_{i, t} \\
\operatorname{Gap}_{i, t}=\beta_{1} \operatorname{Gap}_{i, t-1}+\beta_{2} \text { Saving }_{i, t}+\beta_{3} X_{i, t}+\alpha_{i}+\eta_{t}+\varepsilon_{i, t} \\
\operatorname{Gap}_{i, t}=\beta_{1} \operatorname{Gap}_{i, t-1}+\beta_{2} \text { Corporate }_{i, t}+\beta_{3} X_{i, t}+\alpha_{i}+\eta_{t}+\varepsilon_{i, t}
\end{gathered}
$$

where $i$ represents provinces $(i=1, \cdots, 28)$ and $t$ represents time period $(t=1978, \cdots, 2014) . \quad \beta_{i}$ denotes coefficient; $G_{a p}$ is dependent variables, Gap $_{i, t-1}$ is the lag variable of urban-rural income gap. Fin $n_{i, t} 、 F e_{i, t} 、$ Saving $_{i, t}$, Corporate $_{i, t}$ represent four variables measuring finance development level for province $i$ at year $t: X_{i, t}$ denotes control variables set of province $i$ at year $t$, mainly including PerGDP $P_{i, t}$, Open ${ }_{i, t}$, Human $_{i, t}$, Nonsoe $_{i, t}, G_{i, t}$, and $S_{i, t} ; \alpha_{i}$ represents interprovincial effects; $\eta_{t}$ is the effect of economic policy in transition, denoted by Policy; $\varepsilon_{i, t}$ refers to stochastic error.

\subsection{Variables Definition}

In the setting of indicators, the income gap between urban and rural residents refers to dependent variable; independet variables include four indicators which measure the level of financial development from different aspects, and other control variables that influence urban-rural income gap.

\section{1) Income gap between urban and rural areas}

Although the Gini coefficient can better describe the pattern of income distribution in a country, few data of Gini coefficient at the provincial level. Therefore, the ratio of income of urban residents to that of rural residents is selected to reflect the income distribution gap of urban and rural residents: the greater the ratio, the greater the income gap as well as the more uneven income distribution. Moreover, the statistics of this indicator in China's official statistical yearbook are relatively complete and have comparability and continuity, so we chose this indicator as a representative index to measure the income gap between urban and rural areas in China, that is, the urban-rural income gap (Gap) $=$ real per capita disposable income/per capita net income of rural residents.

\section{2) Financial Development}

As the history of China's securities market development is short and the fi- 
nancing scale is small, China's current financing system is still dominated by banks. Therefore, taking into account the availability of data, this paper does not take into account the impact of securities markets, on the income gap between urban and rural areas. The main indicators of financial development are the financial assets of banks; the greater the indicator, the higher the level of financial development. To describe the financial development of our country more effectively by available statistics, this paper constructs an indicator system to measure the level of China's financial development from three aspects: financial development scale, financial development efficiency, and financial development structure. The four core indicators are as following:

Indicator 1: Fin defines the proportion of total credit to GDP in the whole financial system including banking and non-bank financial institutions. This indicator is mainly used to measure the development scale of the entire financial system. In the developed countries or regions like China, the scale of financial market development is far less than that of the banking system [21]. The financial institutions are highly dominated by banks, and "the proposition of the balance regarding loans from financial institutions accounts" can measure the scale of development of the financial system, the greater the index, the larger scale of China's financial development, the better the financial development.

Indicator 2: $\mathbf{F e}$ defines to the ratio of loans to deposits of financial institutions at the end of one year. This indicator is used to measure the financial efficiency in China. Currently, China's financial system is still largely controlled by the government, so Fe reflects the actual loan rate of financial intermediaries, in order to describe the capability of financial intermediaries to absorb deposits and convert it into loans; the greater the ratio, the greater the financial efficiency, the better the financial development.

Indicator 3: Saving defines the proportion of the total urban and rural household saving deposits accounts for the GDP at the end of the year. This indicator is used as indicator to measure the structure of China's financial system, because it is difficult to obtain specific data on urban and rural areas. It can better describe the capability of China's financial system to incentive household savings and the quality of service for urban and rural residents from financial system the greater the indicator, means that China's financial structure is more reasonable, the better the financial development.

Indicator 4: Corporate defines that the proportion of corporate deposits accounts for the total deposits at the end of the financial year. This is the second indicator to measure the structure of China's financial system in this paper. Hsu, Tian \& Xu [22] argued that Corporate can be used to describe the extent to which the banking system provides financial services to enterprises. The large amount of deposits held by enterprises is primarily for precautionary motivation to respond to the firm's potential investment demands and risk. The larger the proportion of the enterprise deposits, the less financing for enterprises provided by financial institutions, the more irrational the structure of financial develop- 
ment and the worse the financial development.

3) Control Variables

Based on domestic and foreign literature, this paper selected six important control variables to form a set of control variables, which can further reflected the influence of other factors besides financial development on the urban-rural income gap. The set of control variables is as follows:

Control Variables 1: Per Capita (PerGDP)

Because of the serious imbalance of regional development in China, the economic development level and population composition are considerably instinct among provinces. Therefore, this paper selected the actual per capita GDP index excluding the population growth, to depict the actual economic development of a certain region. The indicator can effectively reflect the impact of the macroeconomic environment on urban-rural income disparity. As the level of economic development increases, the government will have more resources and capabilities to focus on the issue of social fairness and excessive income distribution between urban and rural areas, and then to promote the narrowing of income distribution gap between urban and rural areas. As a result, the coefficient of this indicator is supposed to be negative.

Control variable 2: total capital formation $(\mathcal{S})$

Physical capital is the most important material basis for determining the economic development of a country and is the source and motive force for the accumulation of knowledge [23], especially for countries and regions that are still in undeveloped economic. Generally, the academy chose the gross capital formation as the measure of physical capital, so as to calculate the material accumulation of non-financial production in a certain period. In this paper, "the total capital formation as a percentage of GDP" was considered as an indicator to examine the actual capacity of enterprises in production and management. This paper predicted that the coefficient of this indicator should be positive.

Control variable 3: human capital (Human)

The contribution of human capital accumulation to economic growth cannot be neglected in the contemporary knowledge economy. The human capital accumulation can keep increasing scale returns to the whole economy [24] [25] [26]. The key to the accumulation of human capital as "living capital" is to improve the knowledge quality and labor skills of the people themselves and the academy usually used the education as a relevant indicator. As a result, this paper selects the number of students in each province to reflect China's human capital level. Given that human capital accumulation has a long-term positive effect on economic development, this paper argues that this indicator can reflect the inequality of urban and rural education which tend to narrow by the accumulation of human capital that improves the quality of the people and reduces the threshold of human capital investment. Thus it alleviates the imbalance between urban and rural residents income distribution. This paper predictes the coefficient of this indicator should be negative.

Control variable 4: Government consumption expenditure ratio $(G)$ 
The intervention from all levels of China's government in local economic development remained intensive, so this paper selected "local government expenditure as the proportion of GDP" to describe the impact of local economic behavior on urban and rural income gap. In general, all resources, including funds and services provided by the government, are easy to allocate to urban areas, instead of rural areas where lack of those resources. The government expenditure of China mainly also focused on the urban area. The inhabitants of the urban area are more likely to obtain the benefit from it and thus to raise their income level, aggravating the inequality of urban and rural income distribution.

Control variable 5: Percentage of non-SOE workers (Nonsoe)

Nonsoe refers to "the proportion of employees from non-state-owned enterprises in the total number of employees," which is one of the important factors affecting China's urban-rural income gap. China has gradually transformed into a socialist market economic system Since the Reform and Opening. A large number of township enterprises, the private sector, foreign-funded enterprises and other non-state-owned enterprises boosted. The introduction of this indicators describes China's non-public economic development at present. The development of the non-public economy break the original state-owned economy, the "big pot" of egalitarianism, so the coefficient of this indicator should be positive.

Control Variable 6: Economic Openness (Open)

China's foreign trade has boosted, and its scale has been continuously expanded since the Reform and Opening. China's total import and export trade reached 26424.18 billion yuan by 2014. The growth of foreign trade was faster than the growth of world trade in the same period. The development of foreign trade significantly promoted the China's economic development. This paper utilizes "the proportion of total import and export trade accounts for GDP" to measure the scale of China's foreign flow which reflects the degree of China's progressive economy. As China's international trade-related industries have been concentrated in the majority of urban areas, rural areas have few foreign trades and the outcome of increasing foreign trades further enhance the income of urban residents. As a result, the increasing proportion of China's total import and export trade may lead to aggravating the inequality of urban and rural income distribution further. This paper predicted the sign of the coefficient of Open is positive.

Control Variable 7: Policy $_{1994}$

China is a developing countries where undergoes economic transition and whose economic policy is adjusting. The CPC Central Committee 14th session of the Third Plenary Session of the CPC Central Committee enacted "a number decisions on the establishment of a socialist market economic system". The decision called for the establishment of a socialist market economic system, so that the market play a fundamental role under the macroeconomic regulation and the control of resource allocation. Meanwhile, the State Council enacted the "the Decision on Implementing the Financial Management System of Tax-Sharing System" on December 15, 1993, decided to implement the tax-sharing financial 
management system since January 1, 1994, and set up the basic relationship between central and local fiscal distribution under the market economy institutional framework. Therefore, we used two time dummy variables: when the samples were happened in 1994 or later, Policy $_{1994}=1$, otherwise $=0$. The reform of urbanization released the production factors from rural and urban, promoted the urban-rural development, and narrow the gap of residents' income. Hence, this paper predicted the sign of the coefficient of Open is negative.

\subsection{Data Sources}

Given the data span, scholars generally believed that China's statistics after 1978 is more perfect and accurate. We select a large sample of annual data to offset the weakness of short-term data analysis. Hence, the selected panel data includes 37 years (1978-2014). All the relevant data are from the 60 Statistical Yearbook of New China (1949-2009), China Statistical Yearbook (1983-2015), China Financial Yearbook (2014) and the statistical yearbook of relevant provinces. The data for the period from 1978 to 2009 are derived from the compilation of statistical data for the past 60 years (1949-2009), and the data for 2010-2014 are mainly derived from the China Statistical Yearbook (2009-2015).

Geographically, the sample selected in this paper covers 28 provincial administrative units, municipalities, and autonomous regions, excluding Hong Kong, Macao, and Taiwan. Taking into account the lack of data on Tibet-related indicators and its low proportion of total economic output, Hainan Province separated from Guangdong Province in 1987 and the Chongqing Municipality separated from Sichuan Province in 1997, the samples of the Tibet Autonomous Region were removed, and the data for Hainan Province and Chong Qing were incorporated into Sichuan Province and Guangdong Province, respectively. For the integrity and the effectiveness of the data, it should be noted that this paper has made the following adjustment with data:

1) For a few missing data of certain provinces, this paper used 5 -year moving average method for the estimation to maintain the integrity and consistency of panel data.

2) This paper logarithmically processed the data of the urban-rural income gap index, financial development index and control variable, that is, taking the natural logarithm: one purpose is to prevent the variable heteroscedasticity; the another purpose is to better explain the elastic relationship between the indicators through the logarithmical estimated coefficient.

3) To alleviate the data distortions caused by inflation, this paper uses 1978 as the base period (1978) when deflatedly processed the officially published data of per capita GDP, the disposable income of urban residents and net income of rural residents (Year price index of $1978=100$ ).

\subsection{Empirical Methodologies}

Because the panel model can not only observe the time dimension, but also ex- 
amine the cross-sectional dimension and reflect more sample information as well as the high accuracy of the estimation, scholars tend to use the panel model to analyze the relevant problem. Given the possible endogeneity of the panel model, if the traditional econometric method is used, the parameter estimates may be biased and inconsistent and distort the economic meaning of those parameters. The generalized method of moments (GMM), namely dynamic panel data model, which is proposed by Arellano \& Bond [27], is commonly used by scholars to solve this problem. Compared with the traditional econometric method, the superiority of GMM method is that it can solve the endogeneity problem by means of the tool variable (IV) to generate the corresponding moment condition equation. In this paper, we select the lag one period of financial development variables and control variables as our instrumental variables in the GMM model.

\subsection{Empirical Results and Conclusions}

\subsubsection{Statistical Description}

The descriptive statistical results of each variable are reported in Table 2 by Stata 12.0. As shown in Table 2, the average urban-rural income gap is 2.52; the maximum is 4.76 , and the minimum is 0.98 , so the range is large; the standard deviation is 0.69 . Fin, the measurement of financial development size, has the maximum 2.25 and minimum 0.3 (the range is 1.9 ); the standard deviation is 0.31 . The maximum of $\mathrm{Fe}$ is 2.56 , the minimum is 0.35 , and the standard deviation is 0.38 . The mean of Saving and Corporate is 0.48 and 0.34, respectively; the standard deviation of Saving is 0.26 and the standard deviation of Corporate is 0.09 , the range of these two are 1.18 and 0.83 respectively. The mean, standard

Table 2. Descriptive statistics of the variables.

\begin{tabular}{ccccccc}
\hline variables & sample & mean & median & Std.Dev & min & max \\
\hline Gap & 1036 & 2.52 & 2.46 & 0.69 & 0.98 & 4.76 \\
Fin & 1036 & 0.90 & 0.85 & 0.31 & 0.35 & 2.25 \\
Fe & 1036 & 1.09 & 1.07 & 0.38 & 0.36 & 2.56 \\
Saving & 1036 & 0.48 & 0.52 & 0.26 & 0.03 & 1.21 \\
Corporate & 1036 & 0.34 & 0.32 & 0.09 & 0.13 & 17194.49 \\
PerGDP & 1036 & 2398.9 & 1246.7 & 2730.58 & 125.27 & 1.3 \\
S & 1036 & 0.45 & 0.43 & 0.15 & 0.14 & 497.51 \\
Human & 1036 & 71.32 & 30.85 & 81.44 & 3.14 & 0.44 \\
G & 1036 & 0.13 & 0.13 & 0.05 & 0.04 & 0.96 \\
Nonsoe & 1036 & 0.82 & 0.86 & 0.12 & 0.42 & 0.01 \\
\hline
\end{tabular}

Source: Statistical Yearbook of China for 60 years (1949-2009), China Statistical Yearbook (1983-2015), and China Statistical Yearbook of Finance for the calendar year, data are compiled and calculated. 
deviation and maximum and minimum values of PerGDP, S, Human, G, Nonsoe and Open are significantly different as well.

According to the results, China's urban-rural income gap, financial development indicators, human capital, physical capital, economic openness, government expenditure and economic development level and other indicators distribute in large difference. The development is serious imbalanced. This result provided a certain amount of data to support the study of the relationship between financial development and urban-rural income gap at the provincial level, rather than from the national level. It will help us to clarify the relationship and mechanism between China's financial development and income gap from a more micro-level.

\subsubsection{Regression Results}

In this section, we processed the model (3-1) to (3-4) with the system GMM model test and the fixed effect model is used as the robustness test. The regression results are reported in Table 3.

First, this section examined the impact of financial development indicators on the urban-rural income gap measured by Fin, Fe, Saving, and Corporate, respectively. The results of the Table 3 show that there is a significant positive relationship between the financial development scale Fin and the urban-rural income disparity. It demonstrated the expansion of financial scale exacerbates the disparity. The coefficient of the GMM dynamic panel model is equal to 0.153 , indicating that the financial development scale for each increase of $1 \%$, the urban-rural income gap will expand by about $0.153 \%$. After a simple calculation, the standardized coefficient of Fin is: $(0.153 \times 0.31) / 0.69 \times 100 \% \approx 6.87 \%$. Hence, Fin's change can explain $6.87 \%$ of the urban-rural income gap. At the same time, due to the lags of urban and rural income gap-L1.Gap, is significant. This lag will give the urban and rural income gap an increasing cumulative impact, so the cumulative effect of the gap is included. Fin's cumulative effect on urban-rural income disparity is about: $0.153 /(1-0.948) \approx 2.94$, and the coefficient of standardization will increase to $132 \%$. Thus, the scale of financial development has significant impact on the income gap between urban and rural residents.

Next, the financial efficiency Fe has negative effect. The coefficient of GMM dynamic panel model has passed the significance level of $10 \%$, which means that the improvement of financial efficiency will narrow the urban-rural income gap. It also means that China's financial development efficiency will narrow the income gap between urban and rural areas, which may be caused by the implementation of long-term interest rate control in China. Until now the deposit interest rate has not been liberalized. The interest rate is still in partly free floating, distorting the financial development efficiency. China's financial efficiency is declining, indicating that China's current financial development efficiency is still low, however, in Table 3 the coefficient of this indicator in fixed effect model is 
Table 3. Regressions of financial development on the urban-rural income gap.

\begin{tabular}{|c|c|c|c|c|c|c|c|c|}
\hline & \multicolumn{4}{|c|}{ GMM dynamic panel model } & \multicolumn{4}{|c|}{ Fixed-effect panel model } \\
\hline & $\begin{array}{l}\text { Model } \\
(3-1)\end{array}$ & $\begin{array}{l}\text { Model } \\
(3-2)\end{array}$ & $\begin{array}{l}\text { Model } \\
(3-3)\end{array}$ & $\begin{array}{l}\text { Model } \\
(3-4)\end{array}$ & $\begin{array}{l}\text { Model } \\
(3-1)\end{array}$ & $\begin{array}{l}\text { Model } \\
(3-2)\end{array}$ & $\begin{array}{l}\text { Model } \\
(3-3)\end{array}$ & $\begin{array}{l}\text { Model } \\
(3-4)\end{array}$ \\
\hline \multirow[t]{2}{*}{ L1.Gap } & $0.948^{\star * *}$ & $0.989^{* * *}$ & $0.952^{\star * *}$ & $0.945^{\star * *}$ & $0.7523^{* * *}$ & $0.7625^{\star * *}$ & $0.7535^{\star * *}$ & $0.7513^{\star * *}$ \\
\hline & $(22.14)$ & $(32.03)$ & $(24.88)$ & $(18.22)$ & $(30.65)$ & $(28.71)$ & $(28.39)$ & $(24.79)$ \\
\hline \multirow[t]{2}{*}{ Fin } & $0.153^{\star *}$ & & & & $0.0802^{\star * *}$ & & & \\
\hline & $(1.96)$ & & & & $(3.92)$ & & & \\
\hline \multirow[t]{2}{*}{$\mathrm{Fe}$} & & $-0.124^{\star *}$ & & & & -0.0237 & & \\
\hline & & $(-1.96)$ & & & & $(-1.11)$ & & \\
\hline \multirow[t]{2}{*}{ Saving } & & & $0.120^{* * *}$ & & & & $0.0731^{* * *}$ & \\
\hline & & & $(3.11)$ & & & & $(9.72)$ & \\
\hline \multirow[t]{2}{*}{ Corporate } & & & & $-0.108^{\star *}$ & & & & $\begin{array}{c}-0.0419^{\star \star} \\
\star\end{array}$ \\
\hline & & & & $(-2.08)$ & & & & $(-2.93)$ \\
\hline \multirow[t]{2}{*}{ PerGDP } & 0.015 & $0.057^{\star *}$ & 0.017 & $0.056^{* *}$ & $-0.0334^{* *}$ & $-0.0273^{\star *}$ & $-0.0345^{* *}$ & $-0.0243^{\star x}$ \\
\hline & $(0.46)$ & $(2.36)$ & $(0.49)$ & $(2.61)$ & $(-2.35)$ & $(-2.14)$ & $(-2.50)$ & $(-2.03)$ \\
\hline \multirow[t]{2}{*}{ Nonsoe } & -0.238 & 0.041 & -0.148 & -0.050 & $0.0856^{* *}$ & $0.1068^{* *}$ & $0.1119^{* * *}$ & $0.1255^{* *}$ \\
\hline & $(-0.44)$ & $(0.15)$ & $(-0.63)$ & $(-0.24)$ & $(2.30)$ & $(2.30)$ & $(3.55)$ & $(2.49)$ \\
\hline \multirow[t]{2}{*}{ G } & 0.093 & $0.151^{* *}$ & 0.017 & $0.134^{*}$ & $0.0349^{* * *}$ & $0.0377^{\star * *}$ & 0.0015 & $0.0314^{* * *}$ \\
\hline & $(0.66)$ & $(2.13)$ & $(0.17)$ & $(1.95)$ & $(2.72)$ & $(3.37)$ & $(0.15)$ & $(3.01)$ \\
\hline \multirow[t]{2}{*}{$S$} & -0.024 & -0.020 & -0.020 & 0.039 & 0.0203 & $0.0277^{*}$ & -0.0033 & $0.0359^{* *}$ \\
\hline & $(-0.34)$ & $(-0.21)$ & $(-0.26)$ & $(0.69)$ & $(1.26)$ & $(1.90)$ & $(-0.23)$ & $(2.60)$ \\
\hline \multirow[t]{2}{*}{ Open } & -0.018 & 0.001 & -0.038 & -0.002 & $0.0273^{\star * *}$ & $0.0394^{\star * \star}$ & $0.0144^{\star *}$ & $0.0400^{\star * *}$ \\
\hline & $(-0.69)$ & $(0.05)$ & $(-1.46)$ & $(-0.11)$ & $(3.31)$ & $(4.75)$ & $(2.11)$ & $(4.97)$ \\
\hline \multirow[t]{2}{*}{ Human } & -0.010 & -0.021 & -0.002 & $-0.043^{\star *}$ & $0.0323^{\star *}$ & $0.0304^{* * *}$ & $0.0310^{* * *}$ & $0.0237^{\star *}$ \\
\hline & $(-0.36)$ & $(-0.64)$ & $(-0.06)$ & $(-2.07)$ & $(2.49)$ & $(2.74)$ & $(2.69)$ & (1.98) \\
\hline \multirow[t]{2}{*}{$\begin{array}{l}\text { Poli- } \\
\text { cy1994 }\end{array}$} & 0.136 & -0.026 & $-0.092^{\star * *}$ & $-0.040^{\star \star}$ & -0.0096 & 0.0023 & $\begin{array}{c}-0.0419^{\star *} \\
*\end{array}$ & -0.0029 \\
\hline & $(0.41)$ & $(-1.19)$ & $(-6.58)$ & $(-2.16)$ & $(-0.98)$ & $(0.20)$ & $(-4.53)$ & $(-0.28)$ \\
\hline obs & 1008 & 1008 & 1008 & 1008 & 1008 & 1008 & 1008 & 1008 \\
\hline provinces & 28 & 28 & 28 & 28 & 28 & 28 & 28 & 28 \\
\hline $\begin{array}{l}\text { Sargan } \\
\text { test }\end{array}$ & 551.10 & 559.83 & 489.68 & 557.50 & & & & \\
\hline $\mathrm{AR}(2)$ test & 0.18 & 0.13 & -0.48 & -0.34 & & & & \\
\hline $\begin{array}{c}\mathrm{R} \text {-square } \\
\mathrm{d}\end{array}$ & & & & & 0.8826 & 0.8797 & 0.9074 & 0.8845 \\
\hline $\mathrm{F}$ & & & & & 824.69 & 890.27 & 871.13 & 967.19 \\
\hline $\mathrm{p}$ & & & & & 0.0000 & 0.0000 & 0.0000 & 0.0000 \\
\hline
\end{tabular}

Note: $z$-statistics are given in parentheses. ${ }^{* * *},{ }^{* *}$, and ${ }^{*}$ denote significance at the $1 \%, 5 \%$ and $10 \%$ level, respectively. 
insignificant.

The Saving coefficient, one of the indicators of financial structure, is positive. The coefficient of GMM dynamic panel model is 0.120 , which means that urban and rural household income gap will be expanded by about $0.120 \%$ for every $1 \%$ increase in urban and rural household savings. The coefficient is about $4.52 \%$, the cumulative effect is $94.20 \%$, which explained that the change of Saving can significantly expand the income gap between urban and rural areas.

The coefficients of Corporate, the financial structure measurement indicator, are all significantly negative. The coefficient of the GMM dynamic panel model is -0.108 , which means that the gap between the urban and rural incomes will reduce by $0.108 \%$ per $1 \%$ increase in the proportion of corporate savings accounting for GDP. The standardized coefficient is $-1.41 \%$ and the cumulative effect is $-25.61 \%$, which means that the ratio of corporate deposits to GDP declines. The financial structure tends to be optimized, leading to widening income gap further.

To sum up, the increasing level of financial development in term of the scale of financial development and financial structure will lead to a widening trend of income gap between urban and rural areas. The improvement of financial efficiency will reduce the income gap.

Also, the results show that it is significant at the level of $1 \%$ through examining the first order lag L. GAP. The coefficient of the GMM dynamic panel model is estimated to be 0.95 , which means the every $1 \%$ increase of urban-rural income gap of the previous year will lead to a corresponding increase in the next year's urban-rural income gap of $0.95 \%$. The estimation of L.Gap's coefficient indicated that income gap in the previous year does have a significantly positive impact on the next year's income gap, which further aggravates the imbalance of income distribution between urban and rural residents. This result is consistent with the expectation of this paper.

Finally, the coefficient of GDP per capita in the GMM dynamic panel model is positive, while the coefficient in the fixed effect panel model is negative, indicating that the impact of economic development level on urban-rural income disparity is uncertain. Nonsoe's coefficient is either positive or negative when measuring the degree of non-public economic development. However, the significance test is only passed when the coefficient is positive. This indicates that the development of non-state economy enlarges the urban-rural income gap. The coefficients of the control variables $G$, which measures the size of the government's role in the economy, are positive, indicating that the government did not spend enough energy and expenditure to narrow the urban-rural income gap. There is either positive or negative sign of the coefficient of the control variable $S$ which measure the influence of physical capital, indicating that the influence of material capital on income gap is uncertain. Control variable Open that measures the degree of openness of the economy has either positive or negative coefficient, but only pas the significance test when the sign is positive. The sign of 
human resource coefficient is uncertain, and thus the human resource has uncertain influence on urban-rural income gap. The coefficient of Policy1994, which represents the market economy after 1994, has only passed the significant test when negative, indicating that the establishment of market-oriented economic reform narrowed the urban-rural income disparity as a whole.

\subsubsection{Discussion}

This paper analyzes the relationship between financial development and urban-rural income gap based on the system GMM dynamic model and the fixed effect model. As a result, we conclude that the financial development in China aggravated the inequality of income distribution and even caused the widening income gap. Beck \& Levine [28] and Akhter \& Daly [29] have shown that financial development can help narrow the income gap, which is contrary to the empirical results in this paper. Therefore, it is necessary to explore and analyze the mechanism of the relationship between financial development and urban-rural income gap in China.

The theoretical models of Greenwood \& Javanovic [11] and Townsend \& Ueda [12] show that the existence of financial threshold will lead to the initial low income people are excluded from the financial system and cannot access the financial resources and services provided by financial institutions under the financial repression. The high income people who are rich at the beginning are able and willing to pay a certain amount of financial resources and services investment in high-yielding production, investment and construction projects. The rich tend to achieve high profits. The financial threshold effect eventually led to the initial wealth accumulation of two different groups of income distribution situation deteriorated further.

As China's urban areas are far superior to the rural areas in terms of capital, information, human resources and infrastructure for a long time. This chapter aimed to clarify the relationship and the mechanism between financial development and income gap. This paper assumes the urban residents as the high income residents of the threshold effect theory while the rural residents as low income. It is clear that this approximation has a certain rationality. Therefore, we will explain the impact of the unequal allocation of urban and rural financial resources on the urban-rural income distribution pattern based on the financial threshold effect theory.

First, the larger the scale of financial development, which is measured by the proportion of credit, the higher the level of financial development in China. Both the system GMM model and the fixed effect model show that the present situation of urban-rural income distribution disparity will be further deteriorated with the expanding financial development scale. We will explain this phenomenon with the threshold effect of financial development: the urban areas are still the main target of financial service; the existence of financial threshold effect in China leads to that urban residents obtain financial resources and services by virtue of its their own income accumulation and good credits, and in- 
vest them in human capital, management improvement and production, etc. It not only provided a convenient financing channels for urban residents, but injected a large amount of capital into urban development, conducive to the promotion of industrial upgrading and strongly supporting the income growth of urban residents. On the contrary, the wealth accumulation of rural residents is insufficient to bypass the financial threshold to obtain the formal lending resources and services provided by financial intermediaries. This situation is difficult to completely change in the short term, leading to serious rural economic development "ischemia." (leading to the serious "ischemia" of rural economic development) The existence of threshold effect led to the insufficient support for China's agricultural production and farmers from financial institutions. The financial threshold effect will lead to further widening the income gap between urban and rural residents if the scale of financial development in China keeps growing. As a result, it reasonably explains the economic meaning of the financial scale coefficient.

Second, this paper selects the financial institutions' ratio of loans to deposits to measure the level of China's financial efficiency. The greater the indicator, which means that financial intermediaries can absorb savings and convert it into more loans, the higher the efficiency of financial development, the better the financial development. The empirical results in this paper show that Fe coefficient is negative. The higher the efficiency of financial development, the more conducive to the bank which plays the role of project screening as a professional investor. The financial threshold effect should be lower, thereby reducing the income gap between urban and rural residents. The empirical results show that the coefficient of $\mathrm{Fe}$ is significantly negative. However, because there are few effective investment channels in China, residents heavily depend on the bank financial system, residents are over saving, and the ratio of the loan to the savings is continuously declining, the income gap in China was expanding.

Third, this paper sets Saving as the first structural indicator of China's financial development. The greater the proportion of savings deposits of urban and rural household, the better the financial structure and the higher the level of financial development. Both Saving coefficients of the two panel models are significantly positive, indicating that the increase in urban and rural household savings will lead to widening the urban-rural income gap. Analyzing results by the financial development threshold effect: China's financial development is apparently uneven distributed between urban and rural areas. The financial institutions in rural areas lag behind, providing few products and services, and short of channels of formal capital transformation. The rural residents will mainly save income in the form of savings, in order to cope with possible future diseases, natural disasters and their own development or other issues. Rural residents are more likely to save personal income in the form of savings deposits in the formal financial institutions like banks, but in fact, they benefit a little from the savings of interest income in this way and thus lack sufficient investment on production 
and consumption. The urban residents will be able to convert the savings deposits of rural residents into the funding of production, investment, and construction. The income of urban residents increases while the income gap will thus be widened. Given that, we can use the financial threshold effect to explain the impact of the financial structure indicator, which is representative of "urban and rural residents savings deposits" on the urban-rural income gap.

Moreover, this paper uses the proportion of corporate deposits as the second structural indicator of China's financial development. The greater the value of Corporate is, which means the larger proportion of corporate deposits, the more deposits reserved by enterprises for future investment demand. It indicates that the financial institutions do not provide sufficient financial services for enterprises. On the contrary, the small value of Corporate indicates that China's financial structure is reasonable, the financial industry developed well. The empirical results of this chapter show that the Corporate coefficient is significantly negative; that is, the decrease of deposits held by enterprises for preventive motives will lead to the optimization of financial structure and the improvement of financial development level, leading to the widening of urban-rural income gap.

In summary, according to the threshold effect of financial development, this paper clarifies the relationship and mechanism between financial development level and urban-rural income gap in term of financial development scale, financial development efficiency, and financial development structure. The role of the urban-rural income gap is reported in Figure 2. The financial threshold effect exacerbates the serious imbalance in the distribution of financial resources be tween urban and rural areas. The urban-rural income gap will expand with the improvement of the overall financial development level.

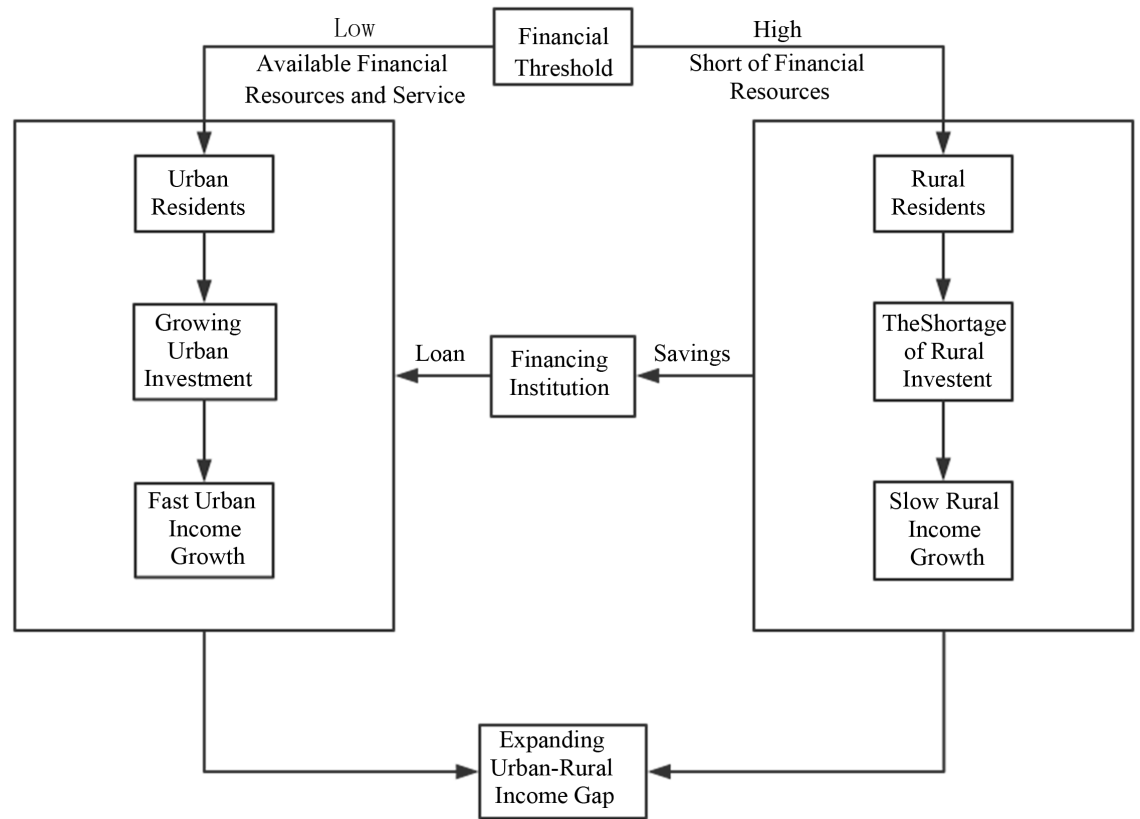

Figure 2. The Mechanism of financial threshold effect on urban-rural income gap. 


\section{The Impact of Urbanization on the Relationship between Financial Development and Urban-Rural Income Gap}

The purpose of this section is to test the relationship among urbanization level, financial development, and income gap between urban and rural residents; then we determined the impact of the development of urbanization on urban-rural income distribution, and how the impact of financial development on the income gap changes through urbanization.

\subsection{Modeling}

Because the GMM model can solve the endogeneity problem better, this paper introduces the "urbanization" index and its interaction with the four financial development indicators in the system GMM dynamic model to study the relationship among China's financial development, urbanization, and the income gap. In this paper, a fixed-effect panel model was also used for the robustness test, and the results are presented together. In this section, the following four models is set:

$$
\begin{aligned}
& \operatorname{Gap}_{i, t}=\beta_{1} \operatorname{Gap}_{i, t-1}+\beta_{2} \operatorname{Urban}_{i, t} \\
& +\beta_{3} \text { Fin }_{i, t}+\beta_{4}\left(\text { Fin }_{i, t} \times \operatorname{Urban}_{i, t}\right) \\
& +\beta_{5} X_{i, t}+\alpha_{i}+\eta_{t}+\varepsilon_{i, t} \\
& \mathrm{Gap}_{i, t}=\beta_{1} \mathrm{Gap}_{i, t-1}+\beta_{2} \operatorname{Urban}_{i, t}+\beta_{3} \mathrm{Fe}_{i, t} \\
& +\beta_{4}\left(\mathrm{Fe}_{i, t} \times \operatorname{Urban}_{i, t}\right) \\
& +\beta_{5} X_{i, t}+\alpha_{i}+\eta_{t}+\varepsilon_{i, t} \\
& \operatorname{Gap}_{i, t}=\beta_{1} \text { Gap }_{i, t-1}+\beta_{2} \text { Urban }_{i, t}+\beta_{3} \text { Saving }_{i, t} \\
& +\beta_{4}\left(\text { Saving }_{i, t} \times \text { Urban }_{i, t}\right) \\
& +\beta_{5} X_{i, t}+\alpha_{i}+\eta_{t}+\varepsilon_{i, t} \\
& \text { Gap }_{i, t}=\beta_{1} \text { Gap }_{i, t-1}+\beta_{2} \text { Urban }_{i, t}+\beta_{3} \text { Corporate }_{i, t} \\
& +\beta_{4}\left(\text { Corporate }_{i, t} \times \text { Urban }_{i, t}\right) \\
& +\beta_{5} X_{i, t}+\alpha_{i}+\eta_{t}+\varepsilon_{i, t}
\end{aligned}
$$

In this section, we introduce the urbanization and its interaction with financial development in model (3-1) and (3-4). Urban $_{i, t}$ represents the urbanization level of province $i$ at time $t . F_{i, t} \times \operatorname{Urban}_{i, t}, F_{i, t} \times \operatorname{Urban}_{i, t}$, Saving $_{i, t} \times$ Urban $_{i, t}$, and Corporate $_{i, t} \times$ Urban $_{i, t}$ represent the interaction between financial development indicators and urbanization. $\varepsilon_{i, t}$ is error term.

\subsection{Empirical Results and Analysis}

The urbanization indicator and its interaction with financial development are introduced in the model from (4-1) to (4-4). The panel statistics of urbanization are: the mean of urbanization level is $38.96 \%$ (the maximum is $90.33 \%$, the minimum is only $8.76 \%$ ); the standard deviation is $17.7 \%$. It shows that China's urbanization development is seriously imbalanced. Second, Table 4 reports the 
Table 4. Regressions of the interaction of urbanization with financial development on the urban-rural income gap.

\begin{tabular}{|c|c|c|c|c|c|c|c|c|}
\hline & \multicolumn{4}{|c|}{ GMM dynamic panel model } & \multicolumn{4}{|c|}{ Fixed-effect panel model } \\
\hline & Model (4 - 1) & Model (4 - 2) & Model (4 - 3) & Model (4 - 4) & Model (4 - 1) & Model (4 - 2) & Model (4 - 3) & Model (4 - 4) \\
\hline \multirow[t]{2}{*}{ L1.Gap } & $0.9346^{* * *}$ & $0.9263^{* * *}$ & $0.9237^{* * *}$ & $0.8255^{\star * *}$ & $0.7534^{* * *}$ & $0.7656^{\star * *}$ & $0.7541^{* * *}$ & $0.7553^{* * *}$ \\
\hline & $(51.70)$ & $(49.77)$ & $(44.24)$ & $(34.66)$ & $(32.27)$ & $(29.73)$ & $(28.44)$ & $(23.95)$ \\
\hline \multirow[t]{2}{*}{ Urban } & $0.1187^{* * *}$ & $0.2244^{* * *}$ & $0.1536^{* * *}$ & $0.4120^{\star * *}$ & -0.0021 & 0.0298 & -0.0006 & 0.0102 \\
\hline & $(3.92)$ & $(8.55)$ & $(4.59)$ & $(10.39)$ & $(-0.11)$ & $(1.56)$ & $(-0.03)$ & $(0.25)$ \\
\hline \multirow[t]{2}{*}{ Fin } & $0.7768^{\star * *}$ & & & & $0.4869^{\star * \star}$ & & & \\
\hline & $(7.27)$ & & & & $(4.76)$ & & & \\
\hline \multirow[t]{2}{*}{ Fin $\times$ Urban } & $-0.1905^{* * *}$ & & & & $-0.1136^{\star * *}$ & & & \\
\hline & $(-6.37)$ & & & & $(-4.02)$ & & & \\
\hline \multirow[t]{2}{*}{$\mathrm{Fe}$} & & $0.8180^{\star * *}$ & & & & $0.2209^{* *}$ & & \\
\hline & & $(5.47)$ & & & & $(2.17)$ & & \\
\hline \multirow[t]{2}{*}{$\mathrm{Fe} \times$ Urban } & & $-0.2289^{* * *}$ & & & & $-0.0723^{\star *}$ & & \\
\hline & & $(-5.74)$ & & & & $(-2.59)$ & & \\
\hline \multirow[t]{2}{*}{ Saving } & & & $0.1379^{\star *}$ & & & & $0.1072^{\star * *}$ & \\
\hline & & & $(2.25)$ & & & & $(2.80)$ & \\
\hline \multirow[t]{2}{*}{ Saving $\times$ Urban } & & & -0.0175 & & & & -0.0113 & \\
\hline & & & $(-0.87)$ & & & & $(-0.95)$ & \\
\hline \multirow[t]{2}{*}{ Corporate } & & & & $-0.7283^{* * *}$ & & & & 0.0546 \\
\hline & & & & $(-5.87)$ & & & & $(0.48)$ \\
\hline \multirow[t]{2}{*}{ Corporate $\times$ Urban } & & & & $0.1820^{\star * \star}$ & & & & -0.0279 \\
\hline & & & & $(5.31)$ & & & & $(-0.88)$ \\
\hline \multirow[t]{2}{*}{ PerGDP } & $-0.0427^{\star \star}$ & $-0.0692^{\star * *}$ & $-0.0594^{* * *}$ & $-0.1454^{\star * *}$ & $-0.0418^{\star *}$ & $-0.0359^{\star *}$ & $-0.0381^{\star *}$ & $-0.0332^{\star *}$ \\
\hline & $(-2.54)$ & $(-4.31)$ & $(-3.48)$ & $(-7.15)$ & $(-2.45)$ & $(-2.26)$ & $(-2.38)$ & $(-2.20)$ \\
\hline \multirow[t]{2}{*}{ Nonsoe } & $0.1852^{\star * *}$ & $0.2713^{\star * *}$ & $0.1615^{* * *}$ & $0.4078^{* * *}$ & $0.2336^{\star * *}$ & $0.2076^{* * *}$ & $0.1517^{\star * *}$ & $0.1717^{\star * *}$ \\
\hline & $(3.37)$ & $(5.35)$ & $(2.94)$ & $(7.47)$ & $(4.82)$ & $(5.21)$ & $(3.70)$ & $(4.07)$ \\
\hline \multirow[t]{2}{*}{ G } & 0.0124 & $0.0569^{\star * *}$ & -0.0015 & $0.0873^{\star * *}$ & 0.0155 & $0.0291^{\star * *}$ & -0.0009 & $0.0266^{\star *}$ \\
\hline & $(0.55)$ & $(2.69)$ & $(-0.07)$ & $(4.10)$ & $(1.46)$ & $(2.76)$ & $(-0.09)$ & $(2.42)$ \\
\hline \multirow[t]{2}{*}{ S } & -0.0143 & $0.0395^{\star *}$ & -0.0017 & $0.1780^{* * *}$ & $0.0286^{*}$ & $0.0336^{* *}$ & 0.0017 & $0.0457^{* * *}$ \\
\hline & $(-0.73)$ & $(2.16)$ & $(-0.08)$ & $(6.51)$ & $(1.80)$ & $(2.00)$ & $(0.11)$ & $(3.18)$ \\
\hline \multirow[t]{2}{*}{ Open } & $-0.0204^{\star \star \star}$ & -0.0071 & $-0.0307^{\star * \star}$ & 0.0076 & $0.0175^{*}$ & $0.0358^{\star * *}$ & $0.0135^{*}$ & $0.0364^{\star * *}$ \\
\hline & $(-3.82)$ & $(-1.34)$ & $(-5.00)$ & $(1.26)$ & $(1.95)$ & $(4.50)$ & $(1.87)$ & $(4.47)$ \\
\hline Human & 0.0070 & 0.0067 & 0.0114 & $0.0286^{\star *}$ & $0.0265^{\star *}$ & $0.0293^{* *}$ & $0.0298^{\star *}$ & 0.0181 \\
\hline
\end{tabular}




\section{Continued}

\begin{tabular}{|c|c|c|c|c|c|c|c|c|}
\hline & $(0.73)$ & $(0.68)$ & (1.19) & $(2.43)$ & $(2.05)$ & $(2.48)$ & $(2.57)$ & $(1.32)$ \\
\hline \multirow[t]{2}{*}{ Policy1994 } & $-0.0620^{* * *}$ & $-0.0692^{* * *}$ & $-0.0850^{* * *}$ & $-0.0328^{\star * *}$ & -0.0144 & -0.0049 & $-0.0402^{\star * *}$ & -0.0082 \\
\hline & $(-6.42)$ & $(-6.29)$ & $(-7.77)$ & $(-3.11)$ & $(-1.54)$ & $(-0.43)$ & $(-4.24)$ & $(-0.79)$ \\
\hline obs & 1008 & 1008 & 1008 & 1008 & 1008 & 1008 & 1008 & 1008 \\
\hline provinces & 28 & 28 & 28 & 28 & 28 & 28 & 28 & 28 \\
\hline Sargan test & 458.15 & 471.30 & 457.17 & 453.11 & & & & \\
\hline $\mathrm{AR}(2)$ test & -0.06 & -0.07 & -0.25 & -0.05 & & & & \\
\hline $\mathrm{R}$-squared & & & & & 0.9147 & 0.8950 & 0.9114 & 0.8933 \\
\hline F & & & & & 606.51 & 599.42 & 745.60 & 806.21 \\
\hline $\mathrm{p}$ & & & & & 0.0000 & 0.0000 & 0.0000 & 0.0000 \\
\hline
\end{tabular}

Note: $z$-statistics are given in parentheses. ${ }^{* *},{ }^{* *}$, and ${ }^{\star}$ denote significance at the $1 \%, 5 \%$ and $10 \%$ level, respectively.

regression results which use GMM dynamic panel model and fixed effect panel model to examine the relationship among financial development, urbanization, and income gap. The AR (2) test results from model (4-1) to (4-4) are all above $10 \%$. We cannot refuse the null hypothesis-there is no second-order sequence correlation for the error term. Thus the four models of urbanization and its interaction are valid.

First, examining the influence of urbanization. In the models (4-1) to (4-4), the coefficient of Urban is significantly positive in the GMM dynamic panel model, and pass the $1 \%$ significance level. It can be inferred that with the increase of urbanization level in China, the acceleration of the urbanization process will have a positive effect on the urban-rural income distribution pattern, widening the income gap further. Statistically, the coefficient of urbanization in the model (4-1) is 0.1187 , which indicates that the income gap will increase by $0.1187 \%$ when the urbanization level of a region increases by $1 \%$. Similarly, the coefficients of Urban in model from (4-2) to (4-4) show that China's income gap will expand by $0.2244 \%, 0.1536 \%$ and $0.4120 \%$, respectively.

Second, we also examined the influence financial development indicators. In Table 4 (GMM dynamic panel model), coefficient signs of Fin, Saving, and Corporate are consistent with the results in Table 3: $1 \%$ increase of Fin will expand $0.7768 \%$ of income gap. Similarly, every $1 \%$ increase of Fe will decrease $0.8180 \%$ income gap. Every $1 \%$ increase of Saving will expand $0.1379 \%$ income gap. Every $1 \%$ increase of Corporate, the proportion of corporate savings, will decline the income gap by $0.7283 \%$. It should be noted that the indexs are identical between Table 3, Table 4, except that the coefficient of Fe was transformed from negative to positve. It is possible that financial threshold decreased with the improving financial efficiency, and then more rural residents are able to access to the financial resources, reducing the urban-rural income gap. However, the financial resources are used to the construction of urbanization and the provi- 
sion of basic services when government promoted the process of urbanization, restraining the efficiency of financial development on the urban-rural income gap.

This section will focus on the economic implications of the four measures of financial development and the urbanization interaction. The regression results in Table 4 show that both the estimated coefficient signs of interactions

Fin $\times$ Urban , Fe $\times$ Urban, and Saving $\times$ Urban are negative and all pass the $1 \%$ significance level, except Saving $\times$ Urban. The estimated coefficients of the urbanization level and the scale of financial development are significantly positive but the coefficient of their interaction is negative. It indicates that the widening effect of urban-rural income gap, caused by increasing financial development scale, will be weakened with the improving urbanization level. In other words, initially, the financial development will lead to widening income gap, however, influenced by the interaction, widening income gap will be alleviated because of the urbanization. The coefficient result of FexUrban illustrates that the financial development indicator, which is measured by financial efficiency, will also weaken the widening effect of income gap in China under the effect of urbanization. The coefficient of Saving $\times$ Urban is negative but insignificant. It indicates that the improvement of the financial structure, measured by the household savings of urban and rural residents will also weaken the income gap under the advancement of the urbanization. The coefficient of Corporate $e_{i, t} \times$ Urban $_{i, t}$ is significantly positive, indicating that the financial development, which is measured by corporate deposits, will weaken the income gap as the urbanization level in China increases. In other words, the higher the proportion of corporate deposits, the stronger the motive of the enterprise's prevention. It means that the more irrational financial development structure will lead to a corresponding narrowing of urban-rural income gap. The existence of interaction will weaken the negative impact of the proportion of corporate deposits, leading to narrow the income gap further.

\subsection{Discussion}

We introduce the urbanization and its interaction with financial development in the empirical model to examine the relationship between financial development, urbanization and income gap, and to analyze how the financial development has different impact on the income distribution pattern between urban and rural residents through urbanization. The empirical results can be summarized as follows: the coefficient of Urban is significantly positive, indicating that it will lead to further income disparity with the acceleration of urbanization and the improvement of urbanization level; The financial development indicators, which are measured by the scale of financial development, financial development efficiency and financial structure, all show that with the increasing level of urbanization in China, the expansion effect of the increase of financial development level on the income gap will weaken. Overall, the income gap still has trend of 
enlargement under the interaction effect of urbanization and financial development.

Based on the analysis above, the income gap between urban and rural residents will be further aggravated with the upgrading urbanization level; on the other hand, the effect of financial development on disparity will be weakened through urbanization mechanism. It means that the effect of financial development on enlarging income gap will weaken, leading to the narrowing income gap.

Todaro's Model [30] showed that rural labor transition, motived by market, is an important channel to improve the urban-rural income disparity. Therefore, the urbanization will narrow the income gap. But our empirical results in this paper show that, with the acceleration of urbanization in China, the income gap in China has not shown as predicted by the classical theory but has aggravated the disparity of urban-rural income distribution further.

The urbanization itself will expand the income gap between urban and rural areas, because urbanization will transform the high-income-high-competence rural residents into urban residents, thereby changing the rural-urban population structure, expanding the urban-rural income gap. In addition, urban areas have the elements agglomeration effect, scale economy effect and the spillover effect, providing a good economic base, abundant financial resource and opportunities for the development of urban residents. The development of urbanization can bring strong support to the local residents' income growth. However, the impact of urbanization on financial development will hinder the narrowing of the income gap between urban and rural areas, and it can also be explained by the financial threshold effect. China's urbanization is mainly dominated by the government in term of the land urbanization, the expansion of the physical city space, instead of the population urbanization. Because rural residents who have entered urban cannot share the same benefits about housing, education and financial services with the urban residents, the restriction of financial threshold effects is still valid to original rural residents. Hence, the impact of urbanization on financial development's restriction on narrowing urban-rural income gap is decreasing.

The empirical results show that the current development of urbanization in China is not well-performed. The quality of urbanization development in China is still low. The newly transferred urban residents are not real fully integrated into the city and also did not enjoy the same rights and interests to promote self-development. Nowadays, urbanization is no longer a simple expansion of the land size and population. We should emphasize the quality of urbanization. The goal of urbanization should benefit all. Especially the allocation of financial resources and services should be compatible with the development of urbanization in China, so that newly urban residents can truly and equally enjoy the financial resources and services. The urbanization process that only aims to increase the proportion of urban population lacks rationality and thus is not con- 
ducive to the healthy urbanization development in China.

\section{Conclusions}

China has made a significant achievement in the economy since Reform and Opening, including the living standard of urban and rural residents, financial development and urbanization. Meanwhile, the problem of irrational distribution of income has become more and more severe, especially in the expanding income gap between urban and rural residents. As the expanding income distribution gap is not conducive to China's economic sustainable development and social stability, to understand the relationship and mechanism among financial development, urbanization, and the uneven urban-rural income distribution is practically essential.

This paper aims to clarify the relationship between financial development, urbanization and income gap between urban and rural areas and their mechanism of action. We select the provincial panel data from 1978 to 2014, respectively, and use system GMM dynamic model and fixed effect static panel model to test. The conclusions are summarized as follows:

First, this paper first discusses the relationship between financial development and urban-rural income gap and analyzes the mechanism under the financial threshold effect. The empirical results show that, at this stage, the improvement of the overall financial development will further increase the income gap and is not conducive to the stability of urban-rural income distribution pattern. Because of the threshold effect of financial development, financial institutions are mainly serving urban residents, leading to a severe uneven financial resources allocation between China's urban and rural areas and eventually aggravating the urban-rural income distribution pattern.

Next, this paper introduces some important factors of urbanization based on our analysis framework. We re-examined the impact of urbanization and its interaction with financial development on the urban-rural income distribution pattern to explore the mechanism of urban-rural dual structure of finance on the evolution of urban-rural income gap under the urbanization. The results are presented as: 1) It will have a positive effect on the income gap between urban and rural areas with the upgrading of the urbanization level, leading to further widening of urban-rural income distribution disparity; 2) The expansion effect of income gap between urban and rural areas caused by financial development will be weakened when influenced by the urbanization, so it will reduce the urban-rural income disparity to a certain extent; 3) Generally, the income gap in China still shows a tendency to expand with the influence of urbanization and its interaction with financial development.

The conclusion is helpful to further clarify the mechanism of income disparity between urban and rural residents in China. This paper will offer the following policies and suggestions:

1) Relieve the financial suppression and further develop the finance industry 
China's financial segmentation between urban and rural is grave. The rural financial system play the role of "pump" while cannot meet the demand of rural finance, leading to long-term "anemia" in rural area. Therefore, feasible measures should be put forward to lift financial repression, to promote the rural financial reform, and to improve the overall efficiency of financial institutions. The establishment of a comprehensive, wide-coverage, and sustainable rural financial system will solve the "Three Agriculture problem" further. On the one hand, the government should encourage and guide commercial financial institutions to serve agriculture, rural areas and farmers. On the other hand, the government should establish a sound policy-oriented financial institution and gradually form a financial system which mainly consist of commercial banks as well as coexist with various policy financial institutions.

2) Improve the quality of urbanization and urbanize the migrant workers

During the urbanization in China, a large number of rural population is the leading force of China's economic development. This part of the population still lagged behind most urban residents in terms of wealth accumulation, credit conditions and loan collateral and still cannot cross the financial threshold.

Nowadays, urbanization is no longer a one-sided expansion in the sense of land size and urban population. More importantly, it needs to emphasize the quality of urbanization. As the development of China's urbanization becomes mature, the government should focus on how to improve the quality of urbanization, in term of welfare, housing, education and employment opportunities, in order to achieve equal treatment. The goal of urbanization should be to bring the achievement to all nationals and to promote the transformation of production mode. In order to reduce the income gap between urban and rural areas, it is imperative to share the financial resources and services with urban residents in a harmonious and equal manner, rather than being limited to only a few groups. Otherwise, merely increasing the proportion of urban population lacks the rationality and thus is not conducive to the healthy development of China's urbanization.

\section{References}

[1] Liu, M.Q. and Yu, J.T. (2008) Financial Structure, Development of Small and Medium Enterprises, and Income Distribution in the People's Republic of China. Asian Development Review, 25, 137-155.

[2] Jalil, A. and Feridun, M. (2011) Long-Run Relationship between Income Inequality and Financial Development in China. Journal of the Asia Pacific Economy, 16, 202 214. https://doi.org/10.1080/13547860.2011.564745

[3] Lu, M. and Chen, Z. (2006) Urbanization, Urban-Biased Policies, and Urban-Rural Inequality in China, 1987-2001. The Chinese Economy, 39, 42-63. https://doi.org/10.2753/CES1097-1475390304

[4] Su, C.W., Liu, T.Y., Chang, H.L. and Jiang, X.Z. (2015) Is Urbanization Narrowing the Urban-Rural Income Gap? A Cross-Regional Study of China. Habitat International, 48, 79-86. https://doi.org/10.1016/j.habitatint.2015.03.002

[5] Levine, R., Levkov, A. and Rubinstein, Y. (2009) Racial Discrimination and Compe- 
tition. NBER Working Paper No.14273.

[6] La Porta, R., Lopez-de-Silanes, F. and Shleifer, A. (2002) Government Ownership of Banks. Journal of Finance, 57, 265-302. https://doi.org/10.1111/1540-6261.00422

[7] Gerschenkron, A. (1962) Economic Backwardness in Historical Perspective. Harvard University Press, Cambridge.

[8] Myrdal, G. (1968) Asian Drama. Pantheon, New York.

[9] Shleifer, A. and Vishny, R.W. (1994) Politicians and Firms. Quarterly Journal of Economics, 109, 995-1025. https://doi.org/10.2307/2118354

[10] Kornai, J. (1979) Resource-Constrained versus Demand-Constrained Systems. Econometrica, 47, 801-819. https://doi.org/10.2307/1914132

[11] Greenwood, J. and Jovanovic, B. (1990) Financial Development, Growth, and the Distribution of Income. Journal of Political Economy, 98, 1076-1107. https://doi.org/10.1086/261720

[12] Townsend, R. and Ueda, K. (2003) Financial Deepening, Inequality, and Growth: A Model-Based Quantitative Evaluation. IMF Working Paper 03-193, International Monetary Fund, Washington DC. http://www.imf.org/external/pubs/ft/wp/2003/wp03193.pdf

[13] Burgess, R. and Pande, R. (2005) Can Rural Banks Reduce Poverty? Evidence from the Indian Social Banking Experiment. American Economic Review, 95, 780-795. https://doi.org/10.1257/0002828054201242

[14] Clarke, G.R.G., Xu, L.C. and Zou, H.F. (2006) Finance and Income Inequality: What Do the Data Tell Us? Southern Economic Journal, 72, 578-596. https://doi.org/10.2307/20111834

[15] Beck, T., Demirgüç-Kunt, A. and Levine, R. (2007) Finance, Inequality and the Poor. Journal of Economic Growth, 12, 27-49. https://doi.org/10.1007/s10887-007-9010-6

[16] Beck, T., Levine, R. and Levkov, A. (2009) Big Bad Banks? The Impact of U.S. Branch Deregulation on Income Distribution. NBER Working Paper No. 13299.

[17] Stopher, P. (1993) Financing Urban Rail Projects: The Case of Los Angeles. Transportation, 20, 229-250. https://doi.org/10.1007/BF01098928

[18] Chang, M., Fu, T. and Chen, J. (2004) Urban Water Investment and Financing in China. Water, 21, 14-18.

[19] Kim, K. (1997) Housing Finance and Urban Infrastructure Finance. Urban Studies, 34, 1597-1630. https://doi.org/10.1080/0042098975367

[20] Cho, S., Wu, J. and Boggess, W.G. (2003) Measuring Interactions among Urbannization, Land Use Regulations, and Public Finance. American Agriculture Economics Association, 98, 988-999. https://doi.org/10.1111/1467-8276.00502

[21] Allen, F., Qian, J. and Qian, M. (2003) Comparing China’s Financial System. China Journal of Finance, 1, 1-28. https://doi.org/10.2139/ssrn.439820

[22] Hsu, P.H., Tian, X. and Xu, Y. (2014) Financial Development and Innovation: Cross-Country Evidence. Journal of Financial Economics, 112, 116-135. https://doi.org/10.1016/j.jfineco.2013.12.002

[23] Scott, J. (1990) Domination and the Arts of Resistance. Yale Univ. Press, New Haven.

[24] Uzawa, H. (1963) On a Two-Sector Model of Economic Growth II. The Review of Economic Studies, 30, 105-118. https://doi.org/10.2307/2295808

[25] Romer, P.M. (1986) Increasing Returns and Long-Run Growth. Journal of Political 
Economy, 94, 1002-1037. https://doi.org/10.1086/261420

[26] Lucas, R.E. (1988) On the Mechanics of Economic Development. Journal of Monetary Economics, 22, 3-42. https://doi.org/10.1016/0304-3932(88)90168-7

[27] Arellano, M. and Bond, S. (1991) Some Tests of Specification for Panel Data: Monte Carlo Evidence and an Application to Employment Equations. The Review of Economic Studies, 58, 277-297. https://doi.org/10.2307/2297968

[28] Beck, T. and Levine, R. (2004) Stock Markets, Banks, and Growth: Panel Evidence. Journal of Banking \& Finance, 28, 423-442.

https://doi.org/10.1016/S0378-4266(02)00408-9

[29] Akhter, S. and Daly, K.J. (2009) Finance and Poverty: Evidence from Fixed Effect Vector Decomposition. Emerging Markets Review, 10, 191-206. https://doi.org/10.1016/j.ememar.2009.02.005

[30] Todaro, M.P. (1969) A Model of Labor Migration and Urban Unemployment in Less Developed Countries. The American Economic Review, 59, 138-148. 